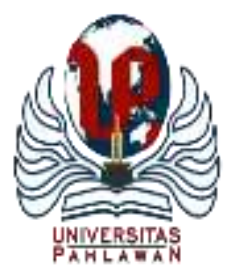

\title{
JURNALBASICEDU
}

Volume 5 Nomor 6 Tahun 2021 Halaman 5249 - 5257

Research \&Learningin Elementary Education https://jbasic.org/index.php/basicedu

\section{Menumbuhkan Karakter Siswa melalui Pemanfaatan Literasi Digital}

\author{
Dinie Anggraeni Dewi', Solihin Ichas Hamid ${ }^{2}$, Farah Annisa ${ }^{3}$, Monica Octafianti ${ }^{4}$, \\ Pingkan Regi Genika ${ }^{5 凶}$ \\ Pendidikan Guru Sekolah Dasar, Universitas Pendidikan Indonesia $1,2,3,4,5$ \\ E-mail: dinieanggraenidewi@upi.edu ${ }^{1}$, solihinichas@upi.edu $^{2}$, farahannisa@upi.edu ${ }^{3}$, \\ monicaoktafianti@upi.edu ${ }^{4}$, pingkanregig@upi.edu ${ }^{5}$
}

\begin{abstract}
Abstrak
Berkembanganya teknologi dalam dunia pendidikan menciptakan banyak sekali kemudahan diantaranya meningkatkan kemampuan belajar dan memudahkan akses dalam pembelajaran. Tetapi, jika penggunaannya tidak diimbangi oleh penanaman pendidikan karakter maka hal itu akan menimbulkan kemerosotan nilai atau krisisnya nilai karakter Pemanfaatan dan pemahaman literasi digital perlu dikembangkan untuk menumbuhkan nilai karakter siswa di abad 21 ini. Tujuan penelitian ini adalah untuk mengetahui manfaat literasi digital dalam pertumbuhan dan pembangunan karakter siswa. Metode penelitian yang digunakan ialah metode deskriptif-kualitatif dengan pendekatan studi pustaka, sumber data diproleh dari hasil analisis dan simpulan yang diperoleh dari jurnal. Hasil analisis dari penelitian ini adalah dalam menumbuhkan karakter siswa di abad 21 literasi digital sangat berperan penting karena anak cenderung lebih tertarik pada hal-hal yang berbau teknologi, youtube dan media sosial lainnya dapat dimanfaatkan oleh guru atau pendidik sebagai wadah untuk meyalurkan pembangunan nilai-nilai karakter. Kesimpulan dari penelitian ini adalah Pemanfaatan literasi digital perlu pengawasan dari orang tua serta guru dengan pemberian atau pembatasan etika digital, agar peserta didik terhindar dari dampak negatif.
\end{abstract}

Kata Kunci: Pendidikan, Literasi Digital, Karakter

\begin{abstract}
The development of technology in the world of education creates a lot of conveniences including increasing learning abilities and facilitating access to learning. However, if its use is not balanced by the cultivation of character education, it will lead to a decline in values or a crisis of character values. The use and understanding of digital literacy needs to be developed to foster student character values in the 21st century. The purpose of this study was to determine the benefits of digital literacy in the growth and development of student character. The research method used is descriptive-qualitative method with a library study approach, the data source is obtained from the results of the analysis and conclusions obtained from the journal. The results of the analysis from this study are that in growing the character of students in the 21 st century, digital literacy plays an important role because children tend to be more interested in things that smell like technology, YouTube and other social media can be used by teachers or educators as a forum to channel the development of values. character. The conclusion of this study is that the use of digital literacy needs supervision from parents and teachers by providing or limiting digital ethics, so that students avoid negative impacts.
\end{abstract}

Keywords: Education, Digital Literacy, Character

Copyright (c) 2021 Dinie Anggraeni Dewi, Solihin Ichas Hamid, Farah Annisa, Monica Octafianti, Pingkan Regi Genika

$\triangle$ Corresponding author :

Email : genikapingkan@gmail.com

DOI : https://doi.org/10.31004/basicedu.v5i6.1609 
5250 Menumbuhkan Karakter Siswa melalui Pemanfaatan Literasi Digital - Dinie Anggraeni Dewi, Solihin Ichas Hamid, Farah Annisa, Monica Octafianti, Pingkan Regi Genika

DOI : https://doi.org/10.31004/basicedu.v5i6.1609

\section{PENDAHULUAN}

Dunia pendidikan menjadi proses para siswa memulai masa belajarnya disekolah. Pendidikan sebagai salah satu seperangkat untuk memenuhi rasa keingintahuan seseorang untuk belajar, berkreatif dan menjadi siswa yang berkarakter. Maka pendidikan adalah usaha membangun karakter manusia yang diselenggarakan dengan rancangan, metode dan strategi yang menyesuaikan di lingkungan. Karakter yang dimiliki bangsa dikembangkan pada karakter tiap individu warganya, dengan demikian karakter dapat dikembangkan mulai dari lingkungan keluarga dan lingkungan sekolah. Kata "character" berasal dari bahasa Yunani charassein, yang berarti to engrave (melukis, menggambar), seperti orang yang melukis kertas, memahat batu atau metal menurut (Sari, 2017). Dengan maksud tersebut dapat diartikan ciri khas khusus dari setiap orang berbeda dengan karakter yang dimilikinya. Karakter sudah ada sejak manusia lahir dan dapat dikembangkan dengan salah satunya pendidikan karakter.

Berdasarkan pendapat diatas, pendidikan karakter yang harus dikembangkan sekolah ialah karakter yang baik, dari segi pendidikan moral, pendidikan budi pekerti, pendidikan religious dan pendidikan watak. Karakter seorang siswa terdapat 18 nilai dalam pendidikan karakter sebagaimana diamanatkan di dalam Kemendiknas dunia pendidikan di Indonesia pada kurikulum 2013 diantaranya religious, jujur, toleransi, disiplin, kerja keras, kreatif, mandiri, demokratis, rasa ingin tahu, semangat kebangsaan, cinta tanah air, menghargai prestasi, bersahabat/komuniktif, cinta damai, gemar membaca, peduli lingkungan, peduli sosial, dan tanggung-jawab. Dengan 18 nilai dalam Pendidikan karakter maka sekolah dapat menyesuaikan kembali dari nilai dasar yang ingin dicapai.

Pendidikan karakter sangat penting untuk memberikan tekanan pada nilai-nilai tertentu seperti rasa hormat, tanggung jawab, jujur, peduli, adil dan membantu siswa untuk memahami, memperhatikan, dan melakukan nilai-nilai tersebut dalam kehidupan mereka sendiri untuk mencapai kesuksesan hidup menurut (Sari, 2017). Pendidikan karakter bertujuan untuk meningkatkan mutu proses dan hasil pendidikan yang mengarah pada pendidikan karakter dan akhlak mulia pembelajar secara utuh, terpadu, dan seimbang, sesuai dengan standar kompetensi lulusan pada setiap satuan pendidikan menurut (UNIGA \& 2017). Di dalam sekolah pendidikan karakter yang siswa dapat terpengaruhi dari lingkungan sosial dan lingkungan budaya. Penanaman pendidikan karakter yang paling utama adalah dari rumah dan keluarga. Keluarga termasuk dari lembaga formal sedangkan lembaga informal salah satunya sekolah yang membentuk pendidikan karakter.

Pendidikan saat ini adanya salah satunya permasalahan karakter siswa. Karakter yang bermasalah pada siswa diantaranya penindasan sesama teman ucapan yang tidak sepantasnya, perilaku yang kurang baik hingga sulit mengikuti pelajaran di sekolah. Bentuk dekadensi moral diantaranya aborsi, prostitusi, tawuran, geng motor, pornografi narkoba dan seks bebas berdasarkan (Murniyetti et al., 2016). Kurang hingga menurunnya Pendidikan karakter pada pembelajaran jarak jauh menjadi tantangan sebuah sekolah. Sekolah berupaya dengan memanfaatkan literasi digital dengan jaman yang serba canggih. Teknologi berkembang pesat bahkan siswa sekolah dasar sudah paham dengan teknologi.

Penelitian ini mencoba mengoptimalkan menumbuhkan karakter siswa melalui pemanfaatan literasi digital. Literasi digital dalam pembelajaran PPKn menjadi upaya yang dapat dilakukan untuk menumbuhkan karaktek siswa. Literasi digital akan mampu menjadi pendombrak dengan aplikasi-aplikasi yang terbuka lebar memudahkan siwa dan guru dalam jangkauannya. Berdasarkan dari Kemdikbud (2016) mengemukakan bahwa memberikan penjelasan Gerakan Literasi Sekolah (GLS) merupakan sebuah upaya yang dilakukan secara menyeluruh untuk menjadikan sekolah sebagai organisasi pembelajaran yang warganya literatur sepanjang hayat melalui pelibatan publik (Kemdikbud. (2016). Berdasarkan uraian diatas, hal inilah yang akan dikaji studi pustaka bagaimana pendidikan karakter dapat menumbuhkan karakter siswa melalui pemanfaatan literasi digital, serta apakah mata pelajaran Pendidikan Kewarganegaarn (PKn) dapat mempengaruhi pendidikan karakter siswa? Sehingga melalui dari hasil studi pustaka dapat memberikan informasi dan 
pengetahuan bagi sebuah Lembaga Pendidikan baik dari formal dan non-formal dari menumbuhkan karakter siswa melalui pemanfaatan literasi digital.

\section{METODE PENELITIAN}

Penelitian ini menggunakan metode deskriptif-kualitatif dengan pendekatan studi pustaka melalui literatur-literatur berupa jurnal, buku, serta artikel ilmiah sebagai objek utama. Penulis memilih metode kualitatif sebagai metode untuk penelitian karena penelitian kualitatif dapat dipertanggung jawabkan keabsahannya dan dapat dipercaya validitas dan reabilitasnya. Validitas data menggunakan triangulasi data yaitu dengan cara memeriksa kebenaran data dengan menggunakan perbandingan antara data dari sumber data yang satu dengan sumber data yang lain, sehingga keabsahan dan kebenaran data akan diuji oleh sumber data yang berbeda.

Data diperoleh dengan cara mencari jurnal, e-book dan skripsi melalui media elektronik (Internet). Melalui Google Cendikia / Google Scholar di lakukan penelusuran dengan mencari kata kunci: Pendidikan, Literasi Digital, Karakter atau Pendidikan Karakter. Jurnal yang dipilih adalah jurnal yang di dalamnya berkaitan dengan kata kunci. Dari hasil penelusuran, peneliti memilih 20 jurnal yang kemudian dianalisis, diringkas dan diklasifikasikan. Sehingga memunculkan ide dan gagasan baru yang masih berhubungan dengan topik pembahasan. Penelitian dalam jurnal tersebut dilakukan guna mengetahui upaya-upaya yang dapat dilakukan untuk meningkatkan dan mengembangkan pendidikan karakter khususnya untuk anak-anak sekolah dasar dalam era globalisasi.

\section{HASIL DAN PEMBAHASAN}

\section{Pendidikan Karakter}

Salah satu media penyalur dalam membantu pembenahan karakter seseorang adalah pendidikan. Salah satu usaha baik yang diselenggarakan sekolah adalah dengan adanya pendidikan karakter, hal tersebut bertujuan untuk meningkatkan para calon generasi bangsa yang berbudi pekerti, peduli serta bertanggung jawab (Marhayani, 2018). Pada siswa sekolah dasar pendidikan karakter merupakan tahapan yang penting dalam pelaksanaan pengembangan karakter siswa, bahkan dapat dikatakan pendidikan karakter ini merupakan hal yang mendasar bagi kesuksesan kemajuan karakter siswa (Anderson \& Sari, 2016). Pendidikan karakter merupakan salah satu proses mendidik seseorang agar memiliki nilai-nilai budi pekerti atau nilai moral yang sesuai dengan aturan yang berlaku dalam masyarakat. Sehingga, pendidikan karakter merupakan sebuah urutan yang teratur untuk mengubah atau memperbaiki dan membangun nilai-nilai baik pada kepribadian siswa yang diselenggarakan oleh pihak penyelenggara pendidikan, lembaga pendidikan memegang kunci utama penanaman karakter dan akhlak peserta didik. Diajarkan tata krama, unggahungguh, sopan santun, kejujuran, rasa tanggung jawab, integritas, disiplin, kerja keras dan sekaligus solidaritas. Kita berharap sekolah dan madrasah menjadi laboratorium karakter dan akhlak selain sebagai kawah candradimuka-nya calon-calon penerus pemimpin bangsa dan negara Indonesia (Dalyono \& Enny Dwi Lestariningsih, 2017).

Senada dengan pandangan sebelumnya mengenai pendidikan karakter bahwa menurut Omeri, N (2015:468) pendidikan karakter merupakan sebuah metode menanamkan nilai-nilai budi pekerti yang mencakup unsur pengetahuan, pemahaman dan tekad, serta usaha untuk menjalankan nilai-nilai tersebut, baik itu hubungannya dengan Tuhan Yang Maha Esa, diri sendiri, sesama makhluk serta lingkungan masyarakat, maupun kewarganegaraan. Sehingga, sebuah bentuk pengaktualan dari nilai-nilai Pancasila adalah pembentukan karakter. Pendidikan karakter dianggap sebagai pendidikan nilai moralitas manusia yang disadari dan dilakukan dalam tindakan nyata (Julaeha, 2019). Melihat persoalan yang berkembang saat ini yang menjadi dasar dalam pendidikan karakter yang dapat dijadikan sebuah solusi untuk membenahi nilai 
5252 Menumbuhkan Karakter Siswa melalui Pemanfaatan Literasi Digital - Dinie Anggraeni Dewi, Solihin Ichas Hamid, Farah Annisa, Monica Octafianti, Pingkan Regi Genika

DOI : https://doi.org/10.31004/basicedu.v5i6.1609

budi pekerti didalam aktivitas siswa ketika menjalani kehidupan berbangsa dan bernegara yang setiap harinya semakin meredup.

Terdapat penguatan pendidikan karakter yang dapat mengatasi persoalan tersebut serta membantu untuk membenahi nilai budi pekerti yang setiap harinya semakin meredup. Terdapat tiga tujuan utama dari karakter yang dipaparkan oleh (Kesuma et al., 2011), yaitu: 1) Dalam pengembangan perilaku siswa yang khusus atau khas diperlukan penguatan dan pengembangan terhadap nilai-nilai kehidupan yang dipandang wajib dan berpengaruh terhadap perilaku siswa. 2) Budi pekerti siswa yang tidak sesuai dengan nilai-nilai yang dikembangkan sekolah perlu untuk diperbaiki atau dibenahi. 3) Menumbuhkan korelasi yang baik dengan masyarakat dan keluarga dalam menjalankan tugas pendidikan karakter. Untuk menumbuhkan Pendidikan karakter di sekolah konsepnya berlandaskan pada visi, misi, dan tujuan sekolah masing-masing yang selanjutnya diimplementasikan (Kamza et al., 2021) ke dalam: 1) kurikulum dan mata pelajaran, 2) budaya sekolah baik di lingkungan guru maupun siswa, dan 3) pengembangan diri melalui program pembiasaan dan pengembangan minat dan bakat siswa. Maka, tonggak penting pendidikan karakter dalam membenahi karakter bangsa serta memanifestasikan masyarakat yang mempunyai budi pekerti yang tinggi, responsif, berkembang secara dinamis serta berpusat pada Ilmu-Ilmu Pengetahuan dan Teknologi (IPTEK).

\section{Literasi Digital}

Literasi digital merupakan salah satu jenis literasi dari berbagai jenis kemajuan literasi yang muncul terhadap perkembangan dan kemajuan teknologi. Literasi digital menurut (Safitri et al., 2020) adalah kemahiran seseorang dalam memahami konten-konten digital. Pemahaman mengenai literasi, mayoritas memahami bahwa hal tersebut hanya sekedar kemahiran untuk membaca dan menulis. Pada periode awal kemajuan literasi, literasi ditafsirkan sebagai kemahiran untuk memakai bahasa dan video dalam wujud yang beragam untuk membaca, menulis, mendengarkan, berbicara, melihat, mengungkapkan dan merefleksikan ide secara kritis. Kemajuan selanjutnya memberitahukan bahwa literasi berkaitan dengan situasi serta penerapan sosial.

Dalam penerapan literasi digital saat ini memudahkan masyarakat untuk lebih bijak dalam memanfaatkan serta mengakses teknologi. Adapun manfaat dalam penerapan literasi digital menurut (Sumiati \& Wijonarko, 2020): 1) Wawasan individu bertambahn ketika melakukan kegiatan mencari dan memahami informasi 2) Menumbuhkan kemahiran seseorang untuk berpikir serta memahami informasi secara lebih kritis 3) Kemampuan verbal individu meningkat 4) Menumbuhkan konsentrasi dan daya fokus individu 5) Kemahiran individu dalam membaca dan menulis informasi bertambah. Berdasarkan manfaat dari diterapkannya literasi digital, memungkinkan literasi digital dapat diterapkan dalam bidang pendidikan. Hal tersebut dapat dijadikan sebagai media untuk pelaksanaan sistem pendidikan yang berbasis digitalisasi. Terlebih seperti pembelajaran daring yang mulai dilakukan saat ini literasi digital dapat memudahkan siswa dalam mengikuti proses pembelajaran, literasi digital berperan mengefektifkan interaksi dan komunikasi selama proses pembelajaran. Sebagai contoh, kemampuan dalam menggunakan fitur kamera dan mikrofon pada perangkatnya agar mampu hadir dan terhubung secara virtual. Lebih jauh, kemampuan menggunakan perangkat lunak untuk menyajikan teks dan gambar pendukungnya (grafik, ilustrasi, dan sebagainya) berperan untuk mengoptimalkan kolaborasi dan komunikasi dalam pembelajaran daring (Irhandayaningsih, 2020).

\section{Pendidikan Kewarganegaraan (PKn)}

Menurut Undang-Undang No.20 Tahun 2003 mengenai Sistem Pendidikan Nasional, pada pasal 37 mengatakan bahwa pendidikan kewarganegaraan wajib termuat dalam kurikulum pendidikan dasar, menengah dan pendidikan tinggi. Secara terminologi, istilah kewarganegaraan merupakan terjemahan dari bahasa inggris "citizenship education" atau "civic education". PKn merupakan syarat awal untuk memajukan individu dan masyarakat secara menyeluruh dalam menghadapi kesulitan dalam aspek kehidupan. PKn secara proaktif terlibat dalam menyongsong dan memajukan pemahaman berdemokrasi. Oleh sebab itu, pendidikan bagi 
5253 Menumbuhkan Karakter Siswa melalui Pemanfaatan Literasi Digital - Dinie Anggraeni Dewi, Solihin Ichas Hamid, Farah Annisa, Monica Octafianti, Pingkan Regi Genika

DOI : https://doi.org/10.31004/basicedu.v5i6.1609

kewarganegaraan bertujuan untuk membekali para pemuda dengan sejumlah kemahiran dasar yang mengharuskan mereka untuk berpatisipasi secara konstruktif dan kritis dalam kehidupan sosial. Pada dasarnya semua mata pelajaran memuat penanaman nilai karakter, namun pada mata pelajaran PKn lebih terfokus pada pengembangan karakter baik bagi siswa agar nantinya dapat menjadi warga negara yang baik oleh (Oktafianti et al., 2021).

Salah satu bidang terbaik dalam pembentukan karakter siswa adalah mata pelajaran PKn, hal ini dikarenakan mata pelajaran PKn merupakan salah satu mata pelajaran yang didalamnya memuat banyak nilainilai karakter (Dewi et al., 2021). Mata pelajaran PKn secara relevan dapat mempengaruhi pengembangan karakter pada siswa, hal ini senada dengan penilitian yang dilakukan oleh (Benaziria, 2018). Pembelajaran PKn dapat mempengaruhi siswa dalam melaksanakan karakter-karakter baik dimana pembelajaran tersebut dilakukan secara baik. Kesimpulan yang dapat diambil dari penelitian tersebut bahwa guru dapat mempengaruhi perkembangan siswa dengan cara menyampaikan PKn dalam proses pembelajaran di kelas. Literasi digital merupakan salah satu karakter yang perlu guru PKn kembangkan kepada siswa untuk membangun kewarganegaraan digital (digital citizenship). Kewarganegaraan digital merupakan watak kewarganegaraan yang mengerti akan literasi digital, yaitu mereka yang dapat bijak dan bertanggung jawab dalam memanfaatkan media digital dan internet. Dalam menumbuhkan serta mengembangkan literasi digital pada peserta didik, maka dalam proses pembelajaran di kelas guru PKn perlu untuk memilih dan menggunakan strategi yang tepat dalam pengembangan literasi digital bagi peserta didik. Maka, implementasi pembentukan karakter kewarganegaraan menurut (Benaziria, 2018) dapat dilakukan dengan dua cara, yaitu pertama, pengajaran secara langsung dalam pembentukan karakter kewarganegaraan (direct teaching). Kedua, pengajaran secara tidak langsung dalam pembentukan karakter kewarganegaraan (indirect teaching).

\section{Menumbuhkan Karakter Siswa melalui Pemanfaatan Literasi Digital}

Literasi digital bukan hanya sekedar kemahiran dalam memanfaatkan peranti lunak atau menjalankan peranti digital saja, akan tetapi literasi digital ialah melingkupi beragam jenis kemahiran kognitif, sosiologis, serta emosional yang bertautan, yang diperlukan pemakai agar dapat berperan secara tepat pada lingkungan digital. Saat ini kapabilitas yang penting bagi siswa ialah kemahiran melek digital (digital literacy). terdapat efek negatif terhadap perilaku anak serta remaja dari penggunaan media digital dan internet berdasarkan beberapa riset yang dilakukan terhadap anak dan remaja Indonesia. Hal tersebut dikarenakan penggunaan media digital dan internet yang kurang pengawasan dari orang tua yang berpengaruh pada penurunan moral anak serta remaja Indonesia, karena tidak semua informasi yang berasal dari media digital serta internet layak untuk dikonsumsi oleh anak dan remaja. Oleh sebab itu, peran guru PKn sangat penting dalam pengembangan literasi digital pada peserta didik. Tujuan diadakannya kegiatan literasi digital di sekolah adalah untuk mengembangkan karakter siswa di abad 21 ini. Pendidikan karakter dapat dilakukan dengan berbagai media, diantaranya penyesuaian menonton mengenai pendidikan selama 15 menit di awal pelajaran melalui manifestasi proyektor (Syafiqo Ahlah \& Melianah, 2020) kemudian melalui pendidikan yang terdapat dari keluarga sebagai pendidik pertama, dan dalam pendidikan yaitu sekolah yang dimulai dari sekolah dasar hingga perguruan tinggi. Adanya pembentukan karakter pada siswa bertujuan sebagai upaya dalam membangun nilai kepedulian, kekerabatan, kedisiplinan serta kejujuran dengan mengarahkan pada karakter atau kepribadian yang baik dikutip dari (Annisa \& Anggraeni, 2021). Upaya yang dilakukan untuk menanamkan pendidikan karakter dalam pendidikan kewarganegaraan ialah dilakukan dengan cara mencantumkan nilai-nilai karakter ke dalam silabus dan RPP menurut (Regi \& Anggraeni, 2021).

Adanya keterkaitan anatara pendidikan serta teknologi yang mengakibatkan sekarang pendidikan mempergunakan sistem e-learning. Sistem ini tidak mengharuskan siswa dan guru untuk bertemu secara langsung atau tatap muka melainkan guru dan siswa dapat menggunakan teknologi canggih seperti laptop, internet, serta gawai. Sistem ini masih memerlukan pembenahan agar dapat menyesuaikan dengan kondisi zaman serta mampu mengadopsi pendidikan karakter untuk para pemuda saat ini. Kemahiran, pengetahuan 
5254 Menumbuhkan Karakter Siswa melalui Pemanfaatan Literasi Digital - Dinie Anggraeni Dewi, Solihin Ichas Hamid, Farah Annisa, Monica Octafianti, Pingkan Regi Genika

DOI : https://doi.org/10.31004/basicedu.v5i6.1609

serta budi pekerti dalam memanfaatkan media digital serta internet merupakan literasi digital yang dikemukakan oleh Calvani dan Cartelli. Seseorang yang mempunyai kemahiran dalam mengidentifikasi, mengelola, mengevaluasi, mengintegrasikan, mensintesis serta menganalisis sumber daya digital merupakan gambaran seseorang yang paham mengenai literasi digital menurut Martin. Terdapat tiga aspek dalam literasi digital yang dapat dipahami yaitu penggunaan digital, transformasi digital, serta kompetensi digital (Benaziria, 2018). Sederhananya media digital terdiri dari berbagai bentuk atau wujud informasi sekaligus seperti tulisan, suara, serta gambar yang dapat dirasakan oleh manusia.

Saat ini, dizaman yang semua aktivitasnya sudah mulai di permudah oleh teknologi. Banyak anak muda yang sudah pandai dalam menggunakan teknologi dibandingkan dengan anak-anak pada zaman sebelum berkembangnya teknologi. Namun, kecanggihan dari teknologi tersebut justru memiliki dampak yang negatif pada anak-anak. Kecanggihan dari teknologi membuat anak-anak muda saat ini kecanduan bahkan melakukan hal-hal yang kurang baik akibat kurangnya pegawasan dari orang tua. Oleh sebab itu, para pendidik perlu untuk memberikan pembelajaran yang dapat membantu peserta didik untuk menjadikan mereka sebagai penerus bangsa yang memiliki tingkah laku serta karakter yang baik. Senada dengan pernyataan tadi bahwa tugas dari seorang pendidik adalah menyediakan lingkungan atau fasilitas belajar yang baik dan mendukung untuk membangun, meningkatkan, serta mengukuhkan karakter atau kepribadian siswa.

Terdapat tujuh dasar mengenai pendidikan karakter perlu untuk disampaikan, yaitu yang pertama, merupakan cara terbaik untuk menjamin peserta didik agar mempunyai kepribadian yang bagus dalam kehidupannya, kedua sebagai tempat untuk membentuk karakter yang kuat dimana di tempat lain siswa tidak mendapatkannya, ketiga sebagai bentuk dalam meningkatkan prestasi akademik siswa, keempat sebagai bentuk perencanaan bagi peserta didik untuk menyegani orang lain serta dapat hidup berdampingan dalam lingkungan yang bermacam-macam, kelima terdapat permasalahan moral sosial, semacam adanya kekerasan, pelanggaran terhadap aktivitas seksual, minimnya semangat belajar atau bekerja, tidak jujur serta tidak sopan, keenam sebagai bentuk perencanaan dalam menghadapi kehidupan di pekerjaan, serta yang ketujuh sebagai bentuk edukasi nilai budaya yang merupakan komponen dari kerja peradaban.

Dengan begitu, Pendidikan kita perlu mengembangkan literasi baru yang tentunya kita harus memahami cara penggunaan teknologi tersebut. Proses pendidikan yang baik juga harus dapat memenuhi kebutuhan dalam literasi manusia, penting untuk bertahan di era revolusi industri ini, tujuannya adalah agar manusia bisa berfungsi dengan baik di lingkungan manusia dan dapat memahami interaksi dengan sesama manusia dalam era yang begitu cepat dalam perkembangan revolusi industri (Fatmawati, 2019). Pemanfaatan kegiatan literasi digital ini sebagai sarana media dalam meningkatkan atau mengembangkan karakter peserta didik yang perlu disertai dengan etika digital, sebagai bentuk dari literasi digital dikembangkan kepada siswa, agar nantinya siswa mampu mempunyai karakter tanggung jawab atau kewajiban dalam peguyuban online untuk menghindari terjadinya kegiatan yang berdampak negatif bagi masyarakat sekitar ataupun daring. Para pendidik dapat memberikan pengetahuan serta keahlian yang lebih tinggi kepada pserta didik mengenai cara mengutarakan ide serta pandangan secara daring, memilih atau menyaring informasi serta membuat konten atau karya secara daring yang memiliki dampak positif bagi orang sekitar.

Adanya kegiatan literasi digital disekolah memiliki tujuan serta manfaat bagi membangun serta meningkatkan karakter peserta didik di era digital. Dalam membangun karakter peserta didik perlunya dilakukan kegiatan literasi digital, dengan cara memanfaatkan platform digital seperti youtube untuk menonton konten-konten yang telah di siapkan oleh pendidik yang nantinya akan ditonton oleh para peserta didik, selanjutnya dalam kegiatan literasi digital ini tidak hanya kegiatan menonton saja tetapi terdapat kegiatan interaksi yang mengajak siswa untuk berpikir kritis dalam memecahkan suatu masalah. Tujuan diadakannya kegiatan literasi digital adalah untuk membangun motivasi peserta didik dalam kegiatan belajar, meningkatkan kemampuan siwa untuk berpikir secara kreatif, serta meningkatkan kepaduan antara peserta didik dan para pendidik. Sehingga, nantinya akan terbentuk para penerus bangsa yang mampu untuk bersaing di era digital saat ini. 
5255 Menumbuhkan Karakter Siswa melalui Pemanfaatan Literasi Digital - Dinie Anggraeni Dewi, Solihin Ichas Hamid, Farah Annisa, Monica Octafianti, Pingkan Regi Genika

DOI : https://doi.org/10.31004/basicedu.v5i6.1609

Adapun hal lain seperti dalam pengelolaan emosi, seseorang akan cenderung mudah tersinggung ketika dia terlalu lama menggunakan handphone atau gawai. Hal tersebut dikarenakan hal-hal yang menarik yang telah disajikan dalam kecanggihan teknologi telah membuat dia begitu terbawa dalam situasi yang nyaman sehingga menunda pekerjaannya. Terdapat beberapa dampak negatif dari adanya perkembangan teknologi ini, salah satunya karakter pada diri seseorang. Adapun dampak bagi peserta didik adalah kecenderungan peserta didik dalam mengakses konten-konten di dalam sosial media atau game yang terdapat dalam gawai. Hal tersebut apabila dibiarkan dan tanpa pengawasan orang tua begitu saja atau orang yang lebih dewasa dapat berbahaya. Berbahaya dalam segi kurangnya etika dalam dunia digital, siswa dapat memberikan komentar yang jahat atau kurang baik di sosial media apabila konten tersebut bertentangan dengan pendapatnya atau yang lainnya.

Berdasarkan sumber jurnal yang kami peroleh bahwa, terdapat pentingnya pemanfaatan literasi digital dalam pembentukan karakter siswa terutama pada siswa sekolah dasar. Melihat dari perkembangan zaman saat ini, dimana teknologi terus berkembang yang mengakibatkan perlunya penyesuaian dengan perkembangan zaman. Di zaman yang serba teknologi, tentunya beberapa kegiatan sudah mulai dipermudah dengan adanya kecanggihan tersebut, namun di sisi lain kecanggihan teknologi tersebut tidak selalu mendatangkan dampak yang positif. Ketika kegiatan sehari-hari dapat dimudahkan dengan kecanggihan teknologi, mulai muncul sifat malas. Hal tersebut dikarenakan kemudahan yang diperoleh dari kecanggihan teknologi tersebut yang membuat seseorang malas untuk melakukan aktivitas. Berdasarkan hasil penelitian yang telah dilakukan oleh (S Ahlah et al., n.d.) bahwa pemanfaatan diadakannya gerakan literasi digital ini adalah dengan tujuan untuk membentuk karakter peserta didik di abad 21 di sekolah. Adapun gerakan literasi digital yang dilakukan di sekolah, dilaksanakan dengan cara menonton tayangan pendidikan di youtube selama 15 menit yang selanjutnya guru memberikan perintah untuk membuat rangkuman terkait tayangan tersebut. Guru dapat memberikan reward kepada peserta didik dengan rangkuman terbaik.

Melihat kenyataan bahwa saat ini anak lebih tertarik menonton youtube peneliti setuju terkait penelitian yang dilakukan oleh (S Ahlah et al., n.d.) bahwa cara tersebut dapat membentuk karakter siswa melalui perkembangan teknologi. Adapun cara lain yang didapatkan peneliti dalam pemanfaatan literasi digital untuk membentuk karakter peserta didik adalah melalui pihak sekolah. Pihak sekolah dapat menyarankan situs belajar kepada peserta didik dengan media pembelajaran berupa laptop atau komputer yang telah tersedia di laboratorium komputer pihak sekolah juga dapat mengenalkan materi pembelajaran digital berbasis gambar, audio, dan visual. Dengan dilaksanakannya gerakan pembelajaran berbasis literasi digital, diharapkan dapat membantu peserta didik untuk memilah milah informasi yang masuk melalui media digital.

\section{KESIMPULAN}

Dari hasil kajian dan penelitian pendidikan karakter dalam lingkungan keluarga, sekolah dan masyarakat penting untuk karakter siswa yang baik jiwa dan raganya. Pendidikan karakter dengan literasi digital menjadi upaya pemenuhan pemanfaatan literasi digital dengan dunia serba teknologi sekarang ini serta menjadi tantangan bagi para Guru. Pengembangan karakter siswa menjadi langkah awal terbentuknya dari keluarga. Pendidikan karakter di sekolah menjadi tahap selanjutnya. Lingkungan keluarga dan sekolah harus selaras untuk menjadi jembatan pada tahap selanjutnya membentuk karakter siswa yang baik. Karena rasa ingin tau yang lebih maka diberi dorongan oleh keluarga dan sekolah untuk siswa nya melakukan literasi digital. Literasi digital dapat dilakukan dimana saja dengan alat komunikasi seperti handphone dan dibuatkan seperti e-book atau e-learning. Dengan melihat kondisi saat pembelajaran jarak jauh sekarang ini dapat memanfaatkan literasi digital sepenuhnya karena peluang lebih banyak siswa belajar dari rumah. Pemanfaatan literasi digital perlu pengawasan dari orang tua serta Guru dengan pemberian atau pembatasan etika digital, sebagai bagian dari literasi digital yang harus ditanamkan kepada peserta didik, agar peserta didik memiliki 
5256 Menumbuhkan Karakter Siswa melalui Pemanfaatan Literasi Digital - Dinie Anggraeni Dewi, Solihin Ichas Hamid, Farah Annisa, Monica Octafianti, Pingkan Regi Genika

DOI : https://doi.org/10.31004/basicedu.v5i6.1609

karakter bertanggung jawab dan terhindar dari dampak negatif baik bagi masyarakat maupun online. Sekolah, guru dan masyarakat dapat mengarahkan literasi digital saat pembelajaran, memberi dorongan dan semangat maka akan tercipta generasi emas dimasa sekarang dan masa yang akan datang yang unggul.

\section{UCAPAN TERIMA KASIH}

Alhamdulillah puji syukur kepada Allah swt, karena kehendak dan ridhaNya peneliti dapat menyelesaikan artikel ini. Peneliti sadari artikel ini tidak akan selesai tanpa doa, dukungan dan dorongan dari berbagai pihak. Adapun dalam kesempatan ini peneliti ingin mengucapkan banyak terima kasih kepada orang tua tercinta dan kepada Ibu Dr. Dinie Anggraeni Dewi, M.Pd da bapak Dr. Solihin Ichas Hamid, M.Pd selaku dosen PKN yang telah memberikan arahan juga motivasi dalam bimbingan kepada penulis dalam menyusun artikel ini juga teman-teman yang dibanggakan serta semua pihak yang tidak dapat disebutkan satu persatu, terima kasih atas segalanya.

\section{DAFTAR PUSTAKA}

Ahlah, S, Nasional, M. M.-P. S., \& 2020, Undefined. (N.D.). Membangun Karakter Siswa Melalui Literasi Digital Dalam Menghadapi Pendidikan Abad 21 Era Society 5.0. Jurnal.Univpgri-Palembang.Ac.Id. Retrieved October 18, 2021, From Https://Jurnal.UnivpgriPalembang.Ac.Id/Index.Php/Prosidingpps/Article/View/3912

Ahlah, Syafiqo, \& Melianah. (2020). Membangun Karakter Siswa Melalui Literasi Digital Dalam Menghadapi Pendidikan Abad 21 Era Society 5.0. Prosiding Seminar Nasional Pendidikan Program Pascasarjana Universitas Pgri Palembang 10 Januari 2020, 805-814.

Anderson, I., \& Sari, R. (2016). Mata Pelajaran Pendidikan. 1(2), 251-274.

Annisa, F., \& Anggraeni, D. (2021). Konstruksi Sosial: Jurnal Penelitian Ilmu Sosial Membangun Karakter Yang Baik Bagi Para Siswa Melalui Pendidikan. 1(8), 1-7.

Benaziria, B. (2018). Pengembangkan Literasi Digital Pada Warga Negara Muda Dalam Pembelajaran Ppkn Melalui Model Vet. Jupiis: Jurnal Pendidikan Ilmu-Ilmu Sosial, 10(1), 11. Https://Doi.Org/10.24114/Jupiis.V10i1.8331

Dalyono, B., \& Enny Dwi Lestariningsih. (2017). Implementasi Penguatan Pendidikan Karakter Di Sekolah. Bangun Rekaprima, 3(3), 33-42.

Dewi, R. R., Suresman, E., \& ... (2021). Pendidikan Kewarganegaraan Sebagai Pendidikan Karakter Di Persekolahan. Asanka: Journal Of ..., 2(1), 79.

Fatmawati, N. I. (2019). Literasi Digital, Mendidik Anak Di Era Digital Bagi Orang Tua Milenial. Madani Jurnal Politik Dan Sosial Kemasyarakatan, 11(2), 119-138.

Irhandayaningsih, A. (2020). Pengukuran Literasi Digital Pada Peserta Pembelajaran Daring Di Masa Pandemi Covid-19. Anuva, 4(2), 231-240.

Julaeha, S. (2019). Problematika Kurikulum Dan Pembelajaran Pendidikan Karakter. Jurnal Penelitian Pendidikan Islam, 7(2), 157. Https://Doi.Org/10.36667/Jppi.V7i2.367

Kamza, M., Husaini, \& Ayu, I. L. (2021). Jurnal Basicedu. Jurnal Basicedu, 5(5), 4120-4126. Https://Doi.Org/10.31004/Basicedu.V5i5.1347

Kemdikbud. (2016). Panduan Gerakan Literasi Sekolah... - Google Scholar. (N.D.). Retrieved October 18, 2021, From Https://Scholar.Google.Com/Scholar?Hl=En\&As_Sdt=0\%2c5\&Q=Kemdikbud.+\%282016\%29.+Pandua $\underline{\text { n+Gerakan+Literasi+Sekolah+Di+Sekolah+Dasar.+Jakarta\%3a+Ditjen+Dikdasmen+Kemdikbud.\&Btng }}$ $\equiv$ 
5257 Menumbuhkan Karakter Siswa melalui Pemanfaatan Literasi Digital - Dinie Anggraeni Dewi, Solihin Ichas Hamid, Farah Annisa, Monica Octafianti, Pingkan Regi Genika

DOI : https://doi.org/10.31004/basicedu.v5i6.1609

Kesuma, D., Triatna, C., \& Permana, J. (2011). Pendidikan Karakter: Kajian Teori Dan Praktik Di Sekolah. Http://R2kn.Litbang.Kemkes.Go.Id/Handle/123456789/73686

Marhayani, D. A. (2018). Pembentukan Karakter Melalui Pembelajaran Ips. Edunomic Jurnal Pendidikan Ekonomi, 5(2), 67. Https://Doi.Org/10.33603/Ejpe.V5i2.261

Murniyetti, M., Engkizar, E., \& Anwar, F. (2016). Pola Pelaksanaan Pendidikan Karakter Terhadap Siswa Sekolah Dasar. Jurnal Pendidikan Karakter, 6(2), 156-166. Https://Doi.Org/10.21831/Jpk.V6i2.12045

Oktafianti, M., Pendidikan, D. D.-A.-T. J., \& 2021, Undefined. (N.D.). Revolusi Karakter Bangsa Melalui Pendidikan Untuk Mengembangkan Warga Negara Yang Baik. Ejournal.Inzah.Ac.Id. Retrieved October 18, 2021, From Https://Www.Ejournal.Inzah.Ac.Id/Index.Php/Attalim/Article/View/546

Regi, P., \& Anggraeni, D. (2021). Konstruksi Sosial: Jurnal Penelitian Ilmu Sosial Pendidikan Kewarganegaraan Dalam Keterkaitan Dengan Pendidikan Karakter Di Indonesia. Junral Penelitian Ilmu Sosial, 1(2), 33-40.

Safitri, I., Marsidin, S., Pendidikan, A. S.-E. J. I., \& 2020, Undefined. (2020). Analisis Kebijakan Terkait Kebijakan Literasi Digital Di Sekolah Dasar. Core.Ac.Uk, 2(2), 176-180. Https://Doi.Org/10.31004/Edukatif.V2i2.123

Sari, A. (2017). Implementasi Pendidikan Karakter Di Sekolah Melalui Kegiatan Pembiasaan Dan Keteladanan. Tarbawi: Jurnal Keilmuan Manajemen Pendidikan, 3(02), 249. Https://Doi.Org/10.32678/Tarbawi.V3i02.1952

Sumiati, E., \& Wijonarko. (2020). Manfaat Literasi Digital Bagi Masyarakat Dan Sektor Pendidikan Pada Saat Pandemi Covid-19. Buletin Perpustakaan Universitas Islam Indonesia, 3(2), 65-80.

Uniga, M. R.-J. P., \& 2017, Undefined. (N.D.). Lingkungan Pendidikan Dalam Implementasi Pendidikan Karakter. Journal.Uniga.Ac.Id. Retrieved October 18, 2021, From Http://Journal.Uniga.Ac.Id/Index.Php/Jp/Article/View/69 